UDC 636.32/.38.082.12

\title{
GENETIC DIVERSITY AND POPULATION STRUCTURE OF BREEDS OF ASKANIAN SHEEP BY ANALYSING POLYMORPHISMS IN QUALITATIVE TRAIT LOCI
}

\author{
V. M. Iovenko, Yu. V. Vdovychenko, N. B. Pysarenko, K. V. Skrepets, I. A. Hladii \\ M. F. Ivanov "Askania Nova” Institute of Animal Breeding in the Steppe Regions - National Scientific Selection-Genetics \\ Center for Sheep Breeding, 75230, Ukraine \\ E-mail:v.n.iovenko49@gmail.com
}

Received April 19, 2019 / Received October 29, 2019 / Accepted March 20, 2019

\begin{abstract}
Aim. To determine the level of polymorphism of some genes, pertaining to the quantitative traits of sheep and to study the genetic diversity and population structure of breeds of Askanian sheep and one of its hybrids. Methods. Molecular-genetic, population-statistical, biometric methods. Results. The genetic structure of populations of the Askanian Fine-Fleeced (AFF, $\mathrm{n}=33)$, Askanian Meat-and-Wool $($ AMW, $\mathrm{n}=22)$ and Askanian Karakul (AK, $n=46)$ breeds and a hybrid of Askanian Fine-Fleeced $\times$ Texel $(A F F T, n=40)$ has been studied for the fi rst time in terms of the polymorphisms of the following qualitative trait genes (loci) : meat productivity genes: ovine growth hormone (GH), calpastatin (CAST) and myostatin (MSTN); prolifi cacy genes: Booroola (fecundity gene FecB) and bone morphogenetic protein (BMP15). The sheep in all studied breeds and the hybrid mentioned above are characterized by the polymorphism of two loci, GH and CAST. The other three loci studied did not show polymorphism for the markers studied. GH is present as two genotypes (A/A, A/B), and CAST as three genotypes (A/A, A/B, B/B). The remaining genes were found to be in the monomorphic state. The frequencies of certain genotypes and alleles change in the direction from fine-fleeced to meat animals. For instance, the concentration of heterozygous growth hormone $(\mathrm{GH})$ genotype $\mathrm{A} / \mathrm{B}$ increases from $0.0 \%$ (AFFB) to $38.2 \%$ (AMWB), and the concentration of allele $\mathrm{A}$ - from 0.083 to 0.191 . The live bodyweight of fine-fleeced lambs with GH genotype $\mathrm{A} / \mathrm{B}$ at birth equaled $4.5 \mathrm{~kg}$, and those with homozygous genotype $\mathrm{A} / \mathrm{A}-4.9 \mathrm{~kg}(\mathrm{P}<0.001)$. Therefore, homozygous genotype A/A determined the increased level of meat productivity of sheep. A similar dependence was established at birth for the Askanian Karakul breed. Conclusions. The specificity of genetic structure of Askanian breeds and hybrid is polymorphism of the GH and CAST and absence of polymorphism of BMP15 and FecB genes, determining the prolificacy (reproduction) trait. According to the distribution of polymorphic loci variants, the gene pools of Askanian Meat-and-Wool breed and the local Askanian-Texel hybrid are closely related and therefore explains the same direction of their productivity. At the same time, all populations are in a state of genetic equilibrium according to Hardy-Weinberg, which indicates a high level of their consolidation. Sheep which have the A/A homozygote of the gene growth hormone are characterized by an increased level of the body weight development.
\end{abstract}

Key words: PCR-RFLP, polymorphism.

DOI:

\section{INTRODUCTION}

Classical selection methods were used when creating the Askanian Fine-Fleeced, Askanian Meat-andWool, Askanian Karakul and Askanian Fine-Fleeced $\times$ $\times$ Texel breeds of sheep.

In current state of the art sheep breeding, the application of selection methods, based on phenotypic assess-

(C) V. M. IOVENKO, YU. V. VDOVYCHENKO,

N. B. PYSARENKO, K. V. SKREPETS, I. A. HLADII 2019 ment of animals only, is a long and not always fruitful path. There is now the possibility of directly evaluating the genetic background, using molecular methods. This is possible via so-called marker-assisted selection (MAS) where these markers are located near the DNA sequence of genes desired for breeding and when present (as detected by molecular methods) through genetic linkage confirm the presence of those desired genes (Bertrand et al., 2007). 
The study of genetic structure of local (domestic) gene pools of different sheep breeds and their hybrids is the first step in the general strategy of MAS, and that is what we have performed and report in the present work. Genetic studies allow assessing allelic diversity of breeds by each target locus, determining polymorphic and monomorphic variants of different genes. Relevance is also attributed to establishing the fact of presence/absence of disturbances (mutations) that endanger the state of genetic equilibrium of a population (the so-called Hardy-Weinberg equilibrium (Merkureva, 1977).

The following step is the investigation of the connection between different allelic variants of genes (socalled qualitative traits loci, or QTLs) and phenotypically complex quantitative traits of sheep of different breeds and productivity directions.

This work presents the results of the determination of the genetic structure (i.e. combining phenotypic trait measurements with genetic data via the study of QTLs of five quality trait genes) of three Askanian sheep breeds and one of its hybrids, Askanian Fine-Fleeced $\mathrm{x}$ Texel which are of different productivity directions. The studied genes are: ovine growth hormone (GH), calpastatin (CAST), myostatin (MSTN), Booroola (FecB), and bone morphogenetic protein (BMP15).

The GH gene is very important in (genetic) breeding efforts of animals. It has a similar structure in many species of vertebrae, in particular, the amino acid sequence of the GH of cattle and sheep has $98.7 \%$ homology (Wallis et al., 1998). In sheep, GL is mapped on chromosome 11 and contains five exons and four introns (Ofir et al., 1997). This gene is involved in acceleration of metabolism and stimulation of the growth of many organs and tissues, especially bones, muscles and internal organs (Akers 2006, Jia et al., 2014). In most investigated sheep it is in a polymorphic state with two allelic variants (Ahlawat et al., 2014).

Meat tenderness is one of the most important quality attributes of meat. Proteolytic enzymes belonging to the calpain family (CAPNs), including calpain I (CAPN1) and calpastatin (CAST) are closely linked to meat tenderness after slaughter in livestock (Ahani et al., 2012). CAST causes specific inhibition of calpain calcium-dependent cysteine protease CAST affects the proteolysis of myofibrilla due to the regulation of calpain, which may initiate the degradation of myofibrilla proteins (thymine and nebulin) after slaughter. The polymorphism of CAST gene consists of three genotypes and two alleles M and N (Shahroudi et al. 2006, Szkudlarek-Kowalezyk et al. 2011).
Myostatin (MSTN) is a member of the TGF-beta superfamily of proteins and is involved in regulating skeletal muscle growth via inhibition of Myo5 and MyoD factors and development as well as muscle catabolism. This gene encodes a member of the TGF-beta (transforming growth factor-beta) family of proteins. Mutations in this gene are associated with increased skeletal muscle mass (Miar et al., 2014). In sheep, the MSTN gene is situated on chromosome 2, it consists of three exons and two introns and has a single-nucleotide polymorphism in the third non-coding region of the gene (Clop A. et al. 2006). The polymorphism of this gene is conditioned by the presence of a mutation, determined by two alleles, but it occurs rather rarely (Zhou et al., 2008). Sheep, homozygous by this mutation, have up to $10 \%$ more muscular weight and $10 \%$ less fat in their body (Boman et al., 2010).

Due to a wide application of sheep as a model species to investigate the genetic control of prolificacy, interesting data were obtained regarding the connection between genetic variability of specific prolificacy loci of different breeds of sheep. Genetic mutations, affecting the number of ovulating eggs and prolificacy, were determined in three genes which belong to the superfamily of the transforming growth factor $\beta$ (TGF $\beta$ ), namely 1 ) Booroola or FecB). The Booroola trait was first noticed in Merino sheep producing large litters on the Booroola Farm in Cooma, Australia. The bone morphogenetic protein IB (BMP-IB) receptor (also known as ALK-6), binding members of the transforming growth factor- $\beta$ (TGF- $\beta$ ) superfamily, is located in the region with the FecB locus., 2) bone morphogenetic factor 15 (BMP15 also known as FecX) and 3) the growth and differentiation factor 9 (GDF9 or FecG) (Davis G. et al. 2002). $\mathrm{FecB}$ is localized on chromosome 6 and increases the ovulation rate with about 1.6 corpora lutea per cycle. Four to twelve eggs mature at once in sheep with this mutation (Mokhtar G. et al. 2009, Montgomery G. et al. 1993, Samik P. et al. 2009). This gene is monomorphic in most investigated breeds of sheep (El-Hanafi A. et al. 2009, Abdoli et al., 2016).

Gene BMP-15 is located on the X-chromosome. This gene regulates the development of oocytes and follicles. Animals, heterozygous by mutation BMP-15, have a higher average number of ovulating eggs compared to wild type genotype. On the contrary, ewes, homozygous by mutation BMP-15, are barren due to the impairment of normal development of follicles at early stages of formation (Galloway S. et al. 2000), (Iheagha-Awemu E. et. al. 2014). In most investigated 
gene pools of sheep in different regions of the world, this gene is monomorphic (Palmer B. et al. 1997, Fogarty, 2009).

\section{MATERIALS AND METHODS}

The study was conducted in the Laboratory of Molecular Genetics of the Askania Nova Institute of Animal Breeding in the Steppe Regions, the National Academy of Agrarian Sciences of Ukraine, using sheep of the breeds Askanian Meat-and-Wool (AMW, $\mathrm{n}=22)$, Askanian Karakul (AK, $\mathrm{n}=46)$, Askanian Fine-Fleeced (AFF, $n=33$ ) and the hybrids of Askanian Fine-Fleeced $\times$ Texel $(\mathrm{AFF} \times \mathrm{T}, \mathrm{n}=40)$.

The polymorphism of the following genes was investigated: meat productivity genes - growth hormone (GH), calpastatin (CAST) and myostatin (MSTN); prolificacy - Booroola (FecB) and bone morphogenetic protein 15 (BMP15).

\section{SAMPLING AND DNA ISOLATION}

In total, 161 blood samples of $4 \mathrm{ml}$ were collected, transported and stored in vacuum Lind-Vac ${ }^{\circledR} \mathrm{K} 2$ EDTA vials. DNA was extracted using the DNA sorb-B nucleic acid extraction kit (AmpliSens ${ }^{\circledR}$ ). The quality of extracted DNA was checked via visualization in $2 \%$ agarose gel using the trans-illuminator.

\section{PCR}

The amplification was conducted using the programmed thermocycler Libe Line (Germany) according to the programs, selected for each locus.

The composition of the reaction mixture for amplification:

$$
4.6 \mu \mathrm{H}_{2} \mathrm{O} \text {; }
$$

Table 1. The primers used for amplification in this study

\begin{tabular}{|c|c|c|}
\hline Locus & Sequence $\left(5^{\prime}-3^{\prime}\right)$ & Product \\
\hline GH & $\begin{array}{l}\text { F: 5'-CTCTGCCTGCCCTGGACT-3' } \\
\text { R: 5'-GGAGAAGCAGAAGGCAAC-3' }\end{array}$ & $422 \mathrm{bp}$ \\
\hline CAST & $\begin{array}{l}\text { F: 5'-TGGGGCCCAATGACGCCATCGATG-3' } \\
\text { R: 5'-GGTGGAGCAGCACTTCTGATCACC-3' }\end{array}$ & $622 \mathrm{bp}$ \\
\hline MSTN & $\begin{array}{l}\text { F 5'-CCG GAG AGA CTT TGG GCT TGA-3' } \\
\text { R5'-TCA TGA GCA CCC ACA GCG GTC-3' }\end{array}$ & $337 \mathrm{bp}$ \\
\hline $\mathrm{FecB}$ & $\begin{array}{l}\text { F: 5'-CCAGAGGACAATAGCAAAGCAAA-3' } \\
\text { R: 5'-CAAGATGTTTTCATGCCTCATCAACACGGTC-3' }\end{array}$ & $190 \mathrm{bp}$ \\
\hline BMP 15 & $\begin{array}{l}\text { F: 5'-TTCTCCGTCTAGGGGTATGAG-3' } \\
\text { R: 5'-AGGGAACAAGAGCAAAGCGTTAGC-3' }\end{array}$ & $356 \mathrm{bp}$ \\
\hline
\end{tabular}

$2.0 \mu 1$ PCR 5-x buffer;

$1.0 \mu \mathrm{dNTP}$ of the mixture $10-\mathrm{x}(2 \mathrm{mM}$ of each);

$0.8 \mu \mathrm{l}$ of two primers (70 ng of each);

$0.1 \mu 1$ Taq-polymerase (1 mol /1000 U);

$1.5 \mu 1$ DNA $50-100 \mathrm{ng}$.

The total volume of the reaction mixture was $10 \mu 1$.

The list of primers, used in the investigation, is presented in Table 1 (GH - Ahlawat A. et al., 2014, CAST - Ahani Azari M. et al., 2012, MSNT - Lazar C. et al. 2016, FecB - Davis G. et al. 2002, BMP15 Shabir M. et al., 2019).

For the GH gene fragment, the PCR was conducted according to the following temperature regimes: one cycle - denaturation at $94{ }^{\circ} \mathrm{C}$ for $5 \mathrm{~min}$; $35 \mathrm{cy}$ cles: denaturation $-95^{\circ} \mathrm{C}, 30 \mathrm{sec}$, annealing - $30 \mathrm{sec}$, $65{ }^{\circ} \mathrm{C}$ and elongation $-72{ }^{\circ} \mathrm{C}, 45 \mathrm{sec}$; one cycle - final elongation at $72{ }^{\circ} \mathrm{C}$ for $7 \mathrm{~min}$. CAST gene fragment: one cycle - denaturation at $94{ }^{\circ} \mathrm{C}$ for $5 \mathrm{~min} ; 33$ cycles: denaturation $-94{ }^{\circ} \mathrm{C}, 15 \mathrm{sec}$, annealing $-30 \mathrm{sec}$, $67{ }^{\circ} \mathrm{C}$ and elongation $-72{ }^{\circ} \mathrm{C}, 30 \mathrm{sec}$; one cycle - final elongation at $72{ }^{\circ} \mathrm{C}, 5 \mathrm{~min}$. MSTN gene fragment: one cycle - denaturation at $95{ }^{\circ} \mathrm{C}$ for $5 \mathrm{~min}$; 33 cycles: denaturation $-95{ }^{\circ} \mathrm{C}, 40 \mathrm{sec}$, annealing $-40 \mathrm{sec}, 67{ }^{\circ} \mathrm{C}$ and elongation $-72{ }^{\circ} \mathrm{C}, 40 \mathrm{sec}$; one cycle - final elongation at $72{ }^{\circ} \mathrm{C}$ for $5 \mathrm{~min}$. FecB gene fragment, PCR: one cycle - denaturation at $94{ }^{\circ} \mathrm{C}$ for $5 \mathrm{~min} ; 33$ cycles: denaturation $-94{ }^{\circ} \mathrm{C}, 15 \mathrm{sec}$, annealing - $30 \mathrm{sec}$ at $60{ }^{\circ} \mathrm{C}$ and elongation $-72{ }^{\circ} \mathrm{C}, 30 \mathrm{sec}$; one cycle - final elongation at $72{ }^{\circ} \mathrm{C}$ for $5 \mathrm{~min}$. BMP 15 gene fragment: one cycle - denaturation at $94{ }^{\circ} \mathrm{C}$ for $5 \mathrm{~min} ; 33$ cycles: denaturation $-94{ }^{\circ} \mathrm{C}, 15 \mathrm{sec}$, annealing $-30 \mathrm{sec}, 62{ }^{\circ} \mathrm{C}$ and elongation $-72{ }^{\circ} \mathrm{C}, 30 \mathrm{sec}$; one cycle - final elongation at $72{ }^{\circ} \mathrm{C}$ for $5 \mathrm{~min}$. 


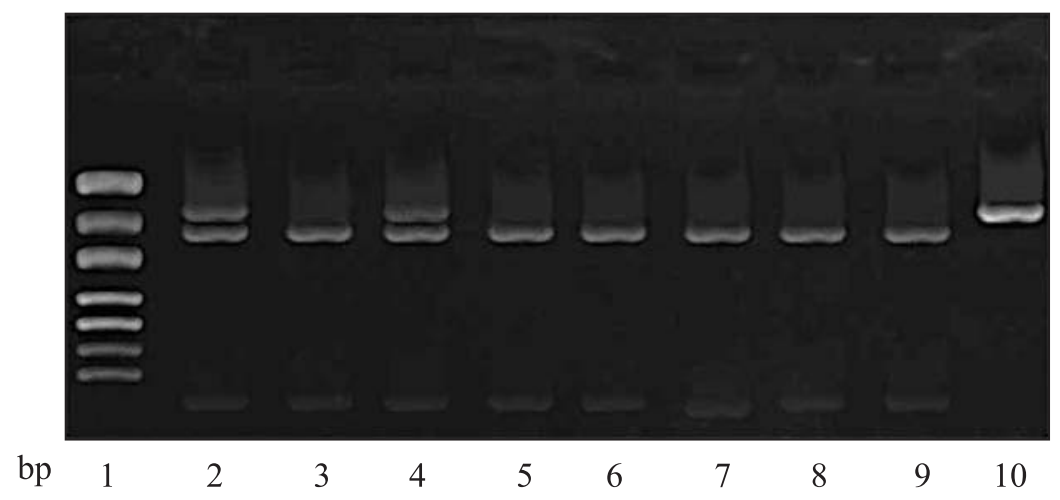

Fig. 1. The electrophoregram of separating GH gene restriction products (restriction enzyme Hae III): 1 - DNA-marker MspI (501, 404, 331, 242, 190, 147, 111bp); 2, 4 - genotype AB (422, 366, 56 bp); 3, 5, 6, 7, 8, 9 - genotype AA (366, 56 bp); 10 - PCR product (422 bp)

\section{RESTRICTION FRAGMENT LENGTH POLYMORPHISM (RFLP) ANALYSIS}

The processing of $10 \mu \mathrm{l}$ amplified fragments was conducted by the following restriction endonucleases: restriction enzym Hae III (GG/CC) was used for $\mathrm{GH}$ gene; MspI (C/CGG) - for CAST; Hae III (GG/CC) - for MSTN; AvaII (G/GACC) - for FecB; Mph1103I (ATGCA/T) - for BMP15, according to standard manufacturer's protocols (Thermo Scientific, USA). The restriction products $(10 \mu \mathrm{l})$ were separated by horizontal electrophoresis in a 2-3\% agarose gel at a voltage of $80 \mathrm{~V}$ for $30 \mathrm{~min}$ using a power supply assembly Neogen SPN300-03C, Ukraine. The visualization was done using ethidium bromide $(0,01 \%)$ and observed under UV light $(312 \mathrm{~nm})$. The size of the restriction fragments was determined using molecular mass markers (Gene Ruler TM 50 bp DNA Ladder of Fermentas (Germany) and pUC19/MspI of Sib Enzim (Russia).

Genotyping for each locus was conducted via the analysis of the obtained electrophoregrams (Ahlawat A. et al. 2014, Shahroudi F. et al. 2006, Zhou I. et al. 2008, Polley S. et al. 2009). The size of the amplification product for each gene is presented in Table 1.

\section{STATISTICS}

The data obtained were used to calculate the observed $(\mathrm{O})$ and expected (E) distribution of genotypes, frequencies of genotypes and alleles, Hardy-Weinberg equilibrium was tested by the Pearson's $\chi^{2}$ goodnessof-fit or chi-squared test, observed $\left(\mathrm{H}_{\mathrm{o}}\right)$ and expected $\left(\mathrm{H}_{\mathrm{e}}\right)$ heterozygosity, effective number of alleles $\left(\mathrm{n}_{\mathrm{e}}\right)$, (Merkureva, 1977). Wright's fixation index (Fis) according to the algorithms of Nei M. et al. 1983. Nagaki's algorithm, 1972 was applied to determine the indices of genetic distance.
To detect the relationships between specific genotypes of GH gene and indices of live bodyweight of animals, young animals of Askanian Meat-and-Wool and Askanian Karakul breeds were studied at birth and at the age of 4 and 6 months.

\section{RESULTS OF INVESTIGATIONS}

Out of five investigated QTL's, RFLP analysis determined different polymorphisms of GH and CAST genes in the three Askanian sheep breeds and one of its hybrids (Fig. 1).

\section{GH}

In case of Hae III - polymorphism for the growth hormone $(\mathrm{GH})$ gene in the investigated populations, two out of three theoretically possible genotypes were found $-\mathrm{A} / \mathrm{A}$ and $\mathrm{A} / \mathrm{B}$. Homozygote $\mathrm{B} / \mathrm{B}$ was absent. Genotype A/A was presented with two fragments, 366 and $56 \mathrm{bp}$ long, genotype A/B - with three fragments, 422, 366 and 56 bp long.

There are considerable differences in the concentration of the genotypes between gene pools (Table 2). For instance, in AFF this gene is presented with only one genotype, homozygote A/A (100\%). In others, its concentration varies from $62.8 \%$ (AMW) to $95.2 \%$ $(\mathrm{AFF} \times \mathrm{T})$. Among local animals, heterozygote A/B was found in one animal (4.8\%), in AK - in five animals (16.7 \%) and in AMW - in 13 animals (38.2\%). The distribution of alleles of this locus is rather contrastive, with absolute predominance of allele $\mathrm{GH}^{\mathrm{A}}$ from 0.809 to 1 .

The monomorphic state of GH locus in the population of the AFF breed (Merino sheep of Ukrainian selection) conditioned a low level of polymorphism in the group of hybrid animals, obtained from the cross-breeding of AFF with meat breed Texel $($ AFF $\times$ T). For instance, 
while in AMW the number of effective alleles equals 1.44 , in $\mathrm{AFF} \times \mathrm{T}$ it is 1.05 . Accordingly, the degree of heterozygosity for $\mathrm{GH}$ is the highest in the population of cross-bred AMW (0.309), and the lowest in AFF $\times$ $\times \mathrm{T}$ (0.047). The gene pool of Karakul (AK) sheep takes middle position for $\mathrm{GH}, \mathrm{n}_{\mathrm{e}}=1.18 ; \mathrm{H}_{\mathrm{E}}-0.152$. Wright's fixation index indicated only a weak excess of heterozygotes for the investigated genes. However, a more substantial number of homozygous animals was found for $\mathrm{GH}-$ locus in AMW population (Fis $=-0.052$ ).

The analysis of observed and expected distribution of different genotypes and calculation of the HardyWeinberg equilibrium for all breeds and hybrid tested, showed that this equilibrium was not impaired. The fluctuations in Fis index values are also within the range of an equilibrium state, indicating a low level of impact of classical breeding work on the genetic structure of sheep herds regarding $\mathrm{GH}$.

\section{CAST}

As for CAST, in all the investigated breeds and one of its hybrids a certain degree of polymorphism occurred with three genotypes (A/A, A/B, B/B) (Fig. 2), determined by two alleles, $\mathrm{CAST}^{\mathrm{A}}$ and $\mathrm{CAST}^{\mathrm{B}}$. The length of the amplicon for this gene is $622 \mathrm{bp}$. restriction enzym Homozygote A/A carriers show two fragments of 336 and $286 \mathrm{bp}$, Heterozygote A/B three (622, 336 and $286 \mathrm{bp}$ ), and homozygote B/B only one (622 bp) fragment.

As for the distribution of genotypes (Table 3), all three genotypes are found only in the Askanian Karakul (AK) breed. Homozygote B/B is absent in the other breeds and hybrid studied. Here the absolute prevalence was noted for homozygote A/A, from $66.7 \%$ (AFF) to $90.9 \%(\mathrm{AMW})$. The frequency of allele $\mathrm{CAST}^{\mathrm{A}}$ is at the level of $0.955-0.826$, and allele $\mathrm{CAST}^{\mathrm{B}}$ at
0.045-0.174. Our results show that the polymorphism degree for CAST in Askanian sheep breeds and hybrid is not high and fluctuates from 1.09 (AMW) to 1.40 (AK). As compared to wool and skin directions, breeds of meat productivity direction do not differ insignificantly in number of effective alleles.

The observed and expected heterozygosity for CAST show virtually equal values for all breeds and hybrid. Thus, all the values of Wright's fixation index equal zero, which demonstrates a low result in classical selection for this locus up till now. This is also confirmed by the value of $\chi^{2}$, whose values equal only $0.0-0.48$, i.e. all the populations are in the state of genetic equilibrium.

In general, the obtained values of genetic population analysis by calpastatin gene are in agreement with the characteristics for other foreign gene funds of sheep, for instance, sheep of Turkish selection (Avanus $K$. 2015, Yilmaz et al., 2014).

The genetic distances between four populations of sheep were estimated based on the obtained data of their genetic structure (Table 4).

It was established that the groups of animals of meat direction, AMW breed and AFFxT, are very closely related $(d=0.005)$. The distance values for the other breeds are considerably higher.

\section{$\mathrm{FecB}$}

While studying the polymorphism of $\mathrm{FecB}$, two alleles were determined, -+ and $\mathrm{B}$. Allele $\mathrm{B}$ is characterized by the presence of a point mutation Q249R in position 746 which leads to the substitution of Gln amino acid for Arg (Abdoli et al., 2016). After restriction, fragments of 160 and $30 \mathrm{bp}$ were revealed in the animals with genotype $\mathrm{B} / \mathrm{B}$. The restriction site for Avall is absent in the carriers of

Table 2. Genetic structure within a limited population of three Askanian sheep breeds and one of its hybrids for the GH-locus

\begin{tabular}{|c|c|c|c|c|c|c|c|c|c|c|c|c|}
\hline \multirow{3}{*}{$\begin{array}{l}\text { Gene } \\
\text { pool }\end{array}$} & \multirow{3}{*}{$\mathrm{n}$} & \multicolumn{4}{|c|}{ Genotype, $\mathrm{n}$} & \multicolumn{2}{|c|}{ Allele frequency } & \multirow{3}{*}{$\mathrm{n}_{\mathrm{e}}$} & \multirow{3}{*}{$\mathrm{H}_{\mathrm{e}}$} & \multirow{3}{*}{$\mathrm{H}_{\mathrm{e}}$} & \multirow{3}{*}{ Fis } & \multirow{3}{*}{$\chi^{2}$} \\
\hline & & \multicolumn{2}{|c|}{ AA } & \multicolumn{2}{|c|}{$\mathrm{AB}$} & \multirow{2}{*}{ A } & \multirow{2}{*}{ B } & & & & & \\
\hline & & $\mathrm{O}$ & E & $\mathrm{O}$ & $\mathrm{E}$ & & & & & & & \\
\hline AMW & 34 & 22.2 & 21 & 10.5 & 13 & 0.809 & 0.191 & 1.44 & 0.325 & 0.309 & -0.052 & 0.60 \\
\hline $\mathrm{AK}$ & 30 & 25.2 & 25 & 4.6 & 5 & 0.917 & 0.083 & 1.18 & 0.153 & 0.152 & -0.007 & 0.04 \\
\hline $\mathrm{AFF}$ & 41 & 41.0 & 41 & - & - & 1.0 & 0.0 & 0.0 & 0.0 & 0.0 & - & - \\
\hline $\mathrm{AFF} \times \mathrm{T}$ & 21 & 20.0 & 20 & 1.0 & 1 & 0.976 & 0.024 & 1.05 & 0.047 & 0.047 & 0.00 & 0.00 \\
\hline
\end{tabular}

Note: here and in Table 3 - $\mathrm{O}$ - observed distribution, $\mathrm{E}$ - expected distribution. 


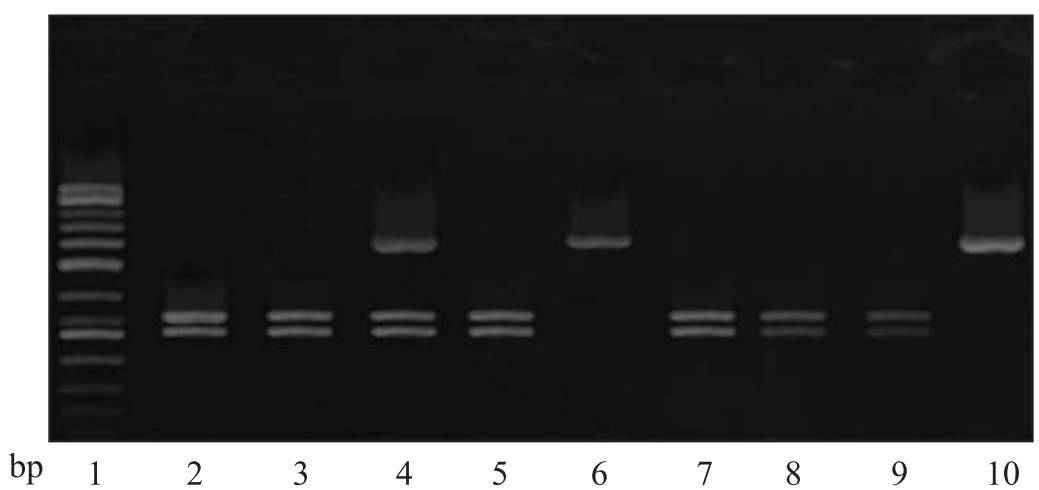

Fig. 2. The electropherogram of separating CAST gene restriction products (restriction enzyme MspI): 1 - DNA-marker GeneRuler TM 50bp DNA Ladder (Fermentas); 2, 3, 5, 7, 8, 9 - genotype AA (336, 286 bp); 4 - genotype AB (622, 336, 286 bp); 6 - genotype BB (622 bp); 10 - PCR product without restriction (622 bp)

genotype $+/+$, while the non-restricted amplification product of $190 \mathrm{bp}$ is present. Heterozygotes with genotype $\mathrm{B} /+$ have three fragments of 30,160 and $190 \mathrm{bp}$.

We found only the fragment of $190 \mathrm{bp}$ which corresponds to homozygous genotype $+/+$ that is related to the wild type (Fig. 3). The absence of mutations in this gene is a remarkable characteristic of Askanian breeds and their hybrids as far as now studied.

\section{BMP 15}

In all the investigated populations of Askanian selection sheep, using restriction enzyme Mph11030 for detection of polymorphism of the gene of (BMP15), only the homozygous genotype of the normal wild type $+/+$ was detected (Fig. 4).

\section{MSTN}

In addition to Booroola gene and bone morphogenetic protein, the locus of myostatin gene was found to be monomorphic too. It was determined that the amplification product is $337 \mathrm{bp}$ when restrictase HaeIII is used. Three DNA fragments, 131, 123 and $83 \mathrm{bp}$, were found in all the investigated animals, and it corresponds to homozygous genotype $\mathrm{m} / \mathrm{m}$ (Fig. 5). Therefore, no mutation, defining the increase in muscular tissue mass of animals, was found in all Askanian breeds and hybrid.

It is known that mutations in different sites of the in-

Table 3. Genetic structure within a limited population of three Askanian sheep breeds and one of its hybrids for the CAST locus

\begin{tabular}{|c|c|c|c|c|c|c|c|c|c|c|c|c|c|c|}
\hline \multirow{3}{*}{$\begin{array}{c}\text { Gene } \\
\text { pool }\end{array}$} & \multirow{3}{*}{$\mathrm{n}$} & \multicolumn{6}{|c|}{ Genotype } & \multicolumn{2}{|c|}{ Allele } & \multirow{3}{*}{$\mathrm{n}_{\mathrm{e}}$} & \multirow{3}{*}{$\mathrm{H}_{\mathrm{E}}$} & \multirow{3}{*}{$\mathrm{H}_{\mathrm{O}}$} & \multirow{3}{*}{ Fis } & \multirow{3}{*}{$\chi^{2}$} \\
\hline & & \multicolumn{2}{|c|}{ AA } & \multicolumn{2}{|c|}{$\mathrm{AB}$} & \multicolumn{2}{|c|}{ BB } & \multirow{2}{*}{ A } & \multirow{2}{*}{ B } & & & & & \\
\hline & & $\mathrm{O}$ & E & $\mathrm{O}$ & E & $\mathrm{O}$ & E & & & & & & & \\
\hline AMW & 22 & 20.0 & 20 & 2.0 & 2 & 0.0 & 0 & 0.955 & 0.045 & 1.09 & 0.086 & 0.086 & 0.0 & 0.0 \\
\hline AK & 46 & 31.4 & 31 & 13.2 & 14 & 1.4 & 1 & 0.826 & 0.174 & 1.40 & 0.287 & 0.287 & 0.0 & 0.32 \\
\hline $\mathrm{AFF}$ & 33 & 22.9 & 22 & 9.2 & 11 & 0.9 & 0 & 0.833 & 0.167 & 1.39 & 0.278 & 0.278 & 0.0 & 0.48 \\
\hline $\mathrm{AFF} \times \mathrm{T}$ & 40 & 36.0 & 36 & 4.0 & 4 & 0.0 & 0 & 0.950 & 0.050 & 1.10 & 0.095 & 0.095 & 0.0 & 0.0 \\
\hline
\end{tabular}

Table 4. The genetic distance between gene pools of sheep of Ukrainian selection

\begin{tabular}{c|c|c|c}
\hline Gene pool & AK & AMW & AFF \\
\hline AMW & 0.129 & - & - \\
AFF & 0.019 & 0.122 & - \\
AFF $\times$ T & 0.127 & 0.005 & 0.117 \\
\hline
\end{tabular}




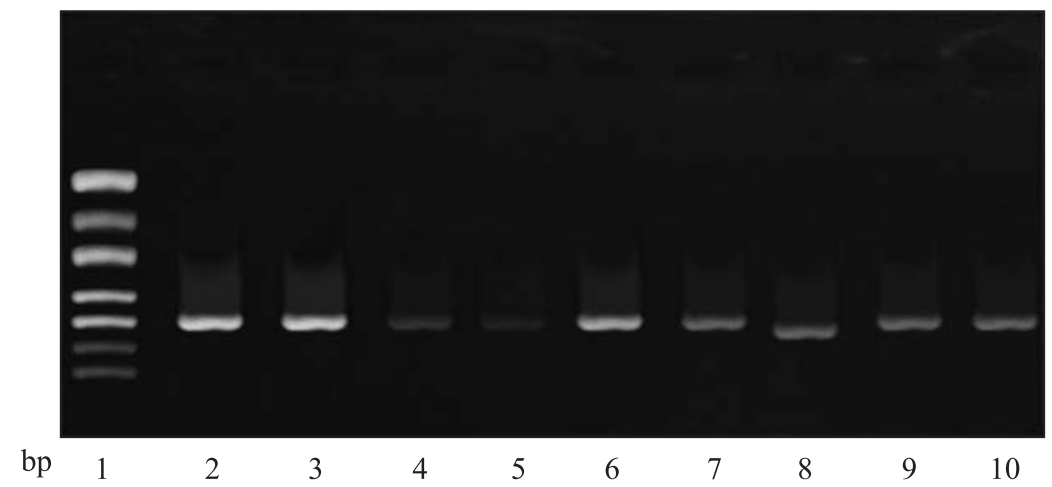

Fig. 3. Electrophoregram of separating restriction products of gene FecB (restrictase AvaII) in sheep: Stripes: 1 - DNAmarker of MspI (501, 404, 331, 242, 190, 147, 111); 2-9 - genotype ++ (190 bp); 10 - PCR product without restriction (190 bp)

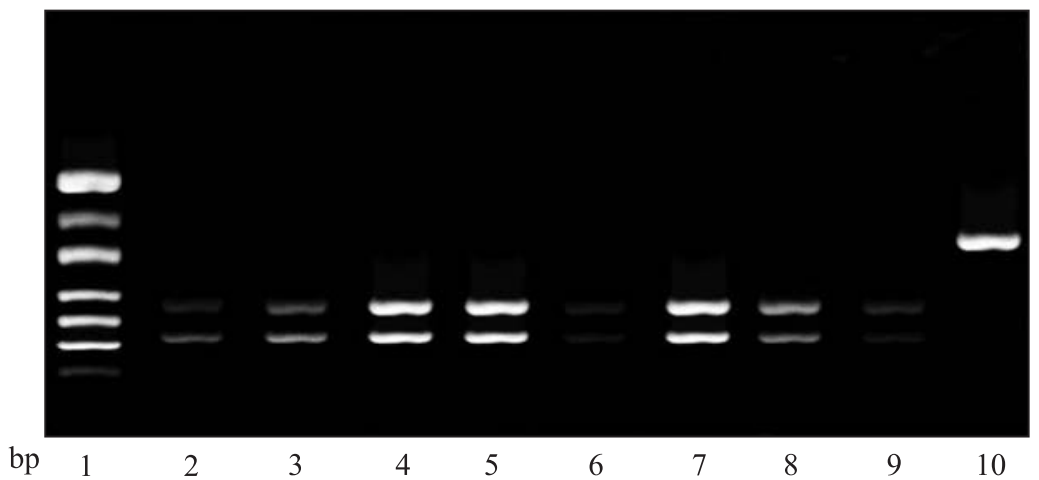

Fig. 4. The electrophoregram of separating the restriction products of gene BMP154 (restrictase Mph1103I) in sheep: Stripes: 1 - DNA-marker MspI (501, 404, 331, 242, 190, 147, 111 bp); 2-9 - genotype ++ (204 and 152 bp); 10 - PCR product without restriction $(356 \mathrm{bp})$

vestigated genes are related to the manifestation and development of specific economically valuable traits of animals, including meat qualities of sheep (Bertrand et al., 2007). This fact may serve as an explanation of interbreed differences in the concentration of genotypes of structural genes, especially a GH gene (Gorlov et al., 2017).

Regardless of the differences in the direction of productivity, the selection for the development of meat productivity of animals is carried out in all the investigated breeds and hybrids, where it is tried to achieve increase in the live bodyweight. This selection process may have impact on the accumulation of homozygotes $\mathrm{A} / \mathrm{A}$ and thus allele $\mathrm{A}$ of the genes of $\mathrm{GH}$ and CAST, as they are part of the genetic background of this trait.

In a separate experiment the Askanian Meat-andWool (AMW) breed and Askanian Karakul (AK) breed were used to demonstrate that from the birth till 6 months of age, homozygous A/A young animals with gene $\mathrm{GH}$ exceed reliably their heterozygous counterparts in the development of their bodyweight $(\mathrm{p}<0.01)$ (Table 5).

\section{DISCUSSION}

PCR and restriction analysis were used to determine polymorphism of growth hormone and calpastatin genes as well as the monomorphic state of the genes of Booroola, myostatin and bone morphogenetic protein in the sheep populations of Askanian selection. In recent decades scientists of most developed countries have been investigating the polymorphism of genes of quantitative traits and thus the study of genetic structure of sheep populations of different origin, so far different results were obtained for different genes. For instance, the data, similar to ours, were obtained for gene GH. In nine breeds of Indian sheep this gene is presented with two genotypes, AA and AB (Kumar R. et al. 2014).

Somewhat different data are presented in several articles regarding gene CAST. For instance, two genotypes were determined in four out of six investigated breeds, and three - in two of them in Turkey (Avanus K. 2015).

While studying the polymorphism of FecB gene, two alternative variants are determined -+ and $\mathrm{B}$. Allele $\mathrm{B}$ is characterized by the presence of a point mutation Q249R in position 746 which leads to the substitution 


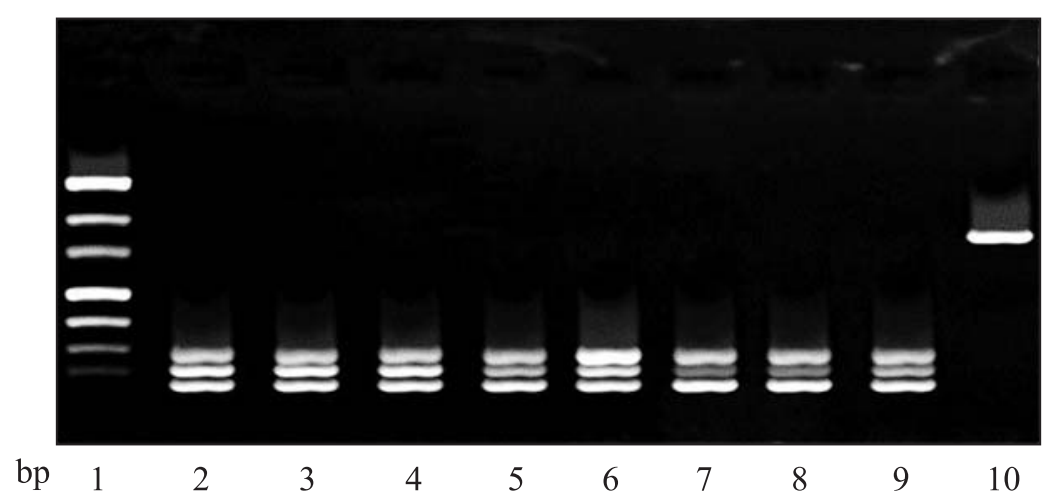

Fig. 5. The electrophoregram of separating the restriction products of gene MSTN (restrictase Hae III) in sheep: Stripes: 1 DNA-marker of MspI (501, 404, 331, 242, 190, 147, 111); 2-9 - genotype mm (131, 123, 83 bp); 10 - PCR product without restriction $(337 \mathrm{bp})$

of Gln amino acid for Arg. After restriction, fragments of 160 and $30 \mathrm{bp}$ are revealed in the animals with genotype $\mathrm{B} / \mathrm{B}$. The restriction site for this restrictase is $a b-$ sent in the carriers of genotype $+/+$, while the non-restriction product of amplification of $190 \mathrm{bp}$ is present. Heterozygotes with genotype $\mathrm{B} /+$ have three fragments at the same time - 30, 160 and 190 bp. (Polley S et al., 2009). The results of comparative analysis demonstrate that in some breeds gene $\mathrm{FecB}$ is in the monomorphic state which is in agreement with our results (Jamshidi R. et al. 2013), while in others it is polymorphic (Guan F. et al. 2006).

The same picture is observed for gene BMP15, which is characterized by the absence of polymorphism in the breeds under our investigation. Still, two allele variants, + and A, can be determined by this gene. Allele $\mathrm{A}$ is characterized by the presence of mutation $\mathrm{FecX} \mathrm{X}^{1}$ in position 299, which leads to the replacement of aminoacid Val with Asp (T > A). After restriction, fragments of 152 and 204 bp are revealed in the animals with genotype $+/+$. The restriction site for restrictase Mph1103 is absent in genotype A/A, while the non-re- striction product of amplification of $356 \mathrm{bp}$ is present. Heterozygotes $\mathrm{A} /+$ are notable for the presence of three fragments - 152, 204 and 356 bp. (Polley S. et al. 2009, Shabiz M. et al. 2012).

As for myostatin (MSTN), most breeds of foreign selection have this gene in the monomorphic state (Jamshidi S. et al. 2014, Dimitrova I. et al. 2016) which is also in the agreement with the results, obtained by us using Askanian selection sheep. Only in several populations it is presented with several alleles (Lazar C. et al. 2016).

Therefore, the results of investigating polymorphism of specific QTL-genes are different for sheep of different breeds, bred in different regions of the planet, which, in our opinion, is related to their origin, the direction of productivity and to the specifics of conducting selection work.

In addition, the change in the ratio of allele frequencies in the series of generations may occur due to genetic hitchhiking as well - as a result of changes in allele concentration, linked to an economically viable trait, resulting from the targeted selection (Hedrick P. 2003, Shahroudi F. et al. 2006). These factors may serve as

Table 5. The live bodyweight of AMWB and AKB lambs of different genotypes by GH locus in different age periods, kg

\begin{tabular}{c|c|c|c|c|c}
\hline \multirow{2}{*}{ Genotype } & \multirow{2}{*}{$\mathrm{n}$} & \multicolumn{3}{c}{ Age } \\
\cline { 3 - 6 } & & At birth & 4 months & 6 months \\
\hline \multicolumn{7}{c}{ Askanian Meat-and-Wool breed } \\
\hline A/A & 21 & $4.9 \pm 0.217$ & $26.7 \pm 0.982$ & $39.0 \pm 0.979$ \\
A/B & 13 & $4.5 \pm 0.268$ & $23.7 \pm 1.002$ & $34.2 \pm 1.084$ \\
\hline A/A & 17 & $4.4+0.252$ & $25.8+0.894$ & $34.4+0.976$ \\
A/B & 5 & $4.0+0.307$ & $22.2+1.170$ & $30.1+1.284$ \\
\hline
\end{tabular}


an explanation for the presence of specific differences between gene pools of sheep of different productivity directions.

Adherence to ethical principles. All procedures performed in studies involving animals participants were in accordance with the ethical standards of the National research committee and with the 1964 Helsinki declaration and its later amendments or comparable ethical standards.

Conflict of interests. The authors declare that they have no conflict of interests.

Support. This study was not funded by any specific grant from financing institutions in governmental, commercial or non-commercial sectors.

\section{Генетична структура популяціяй овець асканійської селекції за поліморфізмом генів кількісних ознак}

В. М. Іовенко, Ю. В. Вдовиченко, Н. Б. Писаренко, К. В. Скрепець, І. А. Гладій

Інститут тваринництва степових районів «Асканія-Нова» - Національний науковий селекційно-генетичний центр з вівчарства НААН смт. Асканія-Нова, Чаплинський р-н, Херсонська обл, Україна, 75230

E-mail: v.n.iovenko49@gmail.com

Мета. Встановити рівень поліморфізму деяких генів кількісних ознак овець та з їх використанням дослідити генетичну структуру популяцій асканійської селекції. Методи. Молекулярно-генетичні, популяційно-статистичні, біометричні. Результати. Вперше досліджено генетичну структуру популяції овець асканійської тонкорунної (n = 33), асканійської м'ясо-вовнової $(\mathrm{n}=22)$, асканійської каракульської (n = 46) та помісей асканійська тонкорунна $\times$ тексель $(\mathrm{n}=40)$ за варіантами структурних генів: гормону росту, калпастатина, міостатина, бурула, кісткового морфогенетичного білка. В усіх досліджених групах вівці характеризуються поліморфізмом двох локусів, гормону росту та калпастатину. Структура першого 3 них представлена двома генотипами (A/A, A/B), другого - трьома (A/A, A/B, B/B). Інші гени знаходяться у мономорфному стані. Аналіз генетичних взаємовідносин між дослідженими генофондами засвідчив, що існує певний зв'язок між вектором продуктивності стад овець та їх молекулярногенетичними параметрами. Так, у напрямку від тонкорунних тварин до м'ясних частоти окремих генотипів i алелей змінюються. Наприклад, концентрація гетерозиготного генотипу А/В гену гормону росту зростає від 0,0 до $38,2 \%$, а алеля А від 0,083 до 0,191. Разом 3 цим, жива маса тонкорунних ягнят з генотипом А/B при народженні рівнялась 4,5 кг, а 3 гомозиготним генотипом A/A $-4,9$ кг $(\mathrm{p}<0,001)$. Аналогічну за- лежність встановлено і в середовищі молодих овець асканійської каракульської породи. Висновки. Особливістю генетичної структури популяцій овець асканійської селекції $є$ відсутність поліморфізму генів, що детермінують ознаку плодючості. За розподілом варіантів поліморфних локусів, що визначають рівень розвитку живої маси тварин, найбільш близькими між собою $€$ генофонди асканійської м'ясо-вовнової породи і помісних тварин, що пояснюється однаковим напрямом їх продуктивності. При цьому всі популяції знаходяться в стані генетичної рівноваги за Харді-Вайнбергом.

Ключові слова: вівці, популяція, ПЛР, ген, поліморфізм, структура.

\section{Генетическая структура популяций овец асканийской селекции за полиморфизмом генов количественных признаков}

В. Н. Иовенко, Ю. В. Вдовиченко, Н. Б. Писаренко, К. В. Скрепец, И. А. Гладий

Институт животноводства степных районов «Аскания-Нова» - Национальный научный селекционно-генетический центр по овцеводству, 75230, Украина

E-mail: v.n.iovenko49@gmail.com

Цель. Установить уровень полиморфизма некоторых генов количественных признаков овец и их использованием изучить генетическую структуру популяций асканийской селекции. Методы. Молекулярно-генетические, популяционно-статистические, биометрические. Результаты. Впервые исследована генетическая структура популяций овец асканийской тонкорунной $(\mathrm{n}=33)$, асканийской мясо-шерстной $(\mathrm{n}=22)$, асканийской каракульской $(\mathrm{n}=46)$ пород и помесей асканийская тонкорунная $\times$ тексель $(\mathrm{n}=40)$ по вариантам структурных генов: гормона роста, калпастатина, миостатина, бурула, костного морфогенетического белка. Во всех исследованных группах овцы характеризуются полиморфизмом двух локусов, гормона роста и калпастатина. Структура первого из них представлена двумя генотипами (A/A, А/B), второго - тремя (A/A, A/B, B/B). Остальные гены находятся в мономорфном состоянии. Анализ генетических взаимоотношений между исследованными генофондами показал, что существует определенная связь между вектором продуктивности стад овец и их молекулярно-генетическими параметрами. Так, в направлении от тонкорунных животных к мясным частоты отдельных генотипов и аллелей изменяются. Например, концентрация гетерозиготного генотипа A/B гена гормона роста увеличивается от 0,0 до $38,2 \%$, а аллеля А от 0,083 до 0,191. Вместе с этим, живая масса тонкорунных ягнят с генотипом A/B при рождении равнялась 4,5 кг, а с гомозиготным генотипом $\mathrm{A} / \mathrm{A}-4,9$ кг $(\mathrm{P}<0,001)$. То есть, последний генетически 
IOVENKO et al.

связан с уровнем мясной продуктивности овец. Аналогичная зависимость установлена и в среде молодых овец асканийской каракульской породы. Выводы. Особенностью генетической структуры популяций овец асканийской селекции является отсутствие полиморфизма генов, детерминирующих признак многоплодия. По распределению вариантов полиморфных локусов, определяющих уровень развития живой массы животных, наиболее близкими между собой являются генофонды асканийской мясо-шерстной породы и помесных животных, что объясняется одинаковым направлением их продуктивности. При этом все популяции находятся в состоянии генетического равновесия по Харди-Вайнбергу.

Ключевые слова: овцы, популяция, ПЦР, ген, полиморфизм, структура.

\section{REFERENCES}

Abdoli R, Zamani P, Mirhoseini S, Ghavi Hossein-Zadeh N, Nadri S. (2016). A review on prolificacy genes in sheep. Reproduction in Domestic Animals. 51:631-7. https:// doi.org/10.1111/rda.12733

Ahlawat AR, Gajbhiye PU, Prince LLL, Meena AS, Dongre $V B$, Gajjar SG. (2014) Genetic polymorphisms in growth hormone gene in Patanwadi, Marwari and Dumba breeds of sheep. Indian J. Anim. Sci. 84(9):1021-2.

Akers RM. (2006) Major advances associated with hormone and growth factor regulation of mammary growth and lactation in dairy cows. J. Dairy Sci. 89(4):1222-34. doi: 10.3168/jds.s0022-0302(06)72191-9.

Ahani Azari M, Dehnavi E, Yousefi S, Shahmohamadi L. (2012) Polymorphism of calpastatin, calpain and myostatin genes in native Dalagh sheep in Iran. Slovak J. Anim. Sci., 45(1):1-6.

Avanus K. (2015) Genetic Variability of GAST Gene in Native Sheep Breeds of Turkey. Kafkas. Univ. Vet. Fak. Derg. 21(6):789-94. doi: 10.9775/kvfd.2015.13138.

Bertrand CY, Collard, David J. Mackill (2007) Markerassisted selection: an approach for precision plant breeding in the twenty-first century. Philos Trans R Soc Lond B Biol Sci. 12:557-72. doi: 10.1098/rstb.2007.2170.

Boman I, Klemetsdal G, Nafstad O, Blichfeldt T, Våge D. (2010) Impact of two myostatin (MSTN) mutations on weight gain and lamb carcass classification in Norwegian White Sheep (Ovis aries). Genetics, selection, evolution. 42(1):4. doi: 10.1186/1297-9686-42-4.

Clop A, Marcq F, Takeda H, Pirottin D, Tordoir X, Bibé $B$, Bouix J, Caiment F, Elsen JM, Eychenne F, Larzul $C$, Laville E, Meish F, Milenkovic D, Tobin J, Charlier $C$, Georges M. (2006) A mutation creating a potential illegitimate microRNA target site in the myostatin gene affects muscularity in sheep. Nature. Genet. 38(7):813-8. doi: $10.1038 / \mathrm{ng} 1810$.

Davis GH, Galloway SM, Ross IK, Gregan SM, Ward J, Nimbkar BV, Ghalsasi PM, Nimbkar C, Gray GD, Subandriyo Inounu I, Tiesnamurti B, Martyniuk E, Eytho- rsdottir E, Mulsant Ph, Lecerf F, Hanrahan JP, Bradford GE, Wilson T. (2002) DNA tests in prolific sheep from eight countries provide new evidence on origin of the Booroola (FecB) mutation. Biol. Reprod. 66(6):1869-74. https://doi.org/10.1095/biolreprod66.6.1869.

Dimitrova I, Bozhilova-Sakova M, Stancheva N, Tzonev T. (2016) Molecular analysis of ovine myostatin gene (MSTN) in northeast Bulgarian merino sheep breed using PCR-RFLP. Bulgar. J. Agric. Sci. 22(2):1-3.

El-Hanafy AA, El-Saadani MA. (2009) Fingerprinting of FECB gene in five Egyptian sheep breeds. Biotechnol. Anim. Husband. 25(3-4):205-12.

Galloway SM, McNatty KP, Cambridge LM, Laitinen MPE, Juengel JL, Jokiranta TS, McLaren RJ, Luiro K, Dodds $K G$, Montgomery GW, Beattie AE, Davis GH, Ritvos $O$. (2000) Mutations in an oocyte-derived growth factor gene (BMP15) cause increased ovulation rate and infertility in a dosage-sensitive manner. Nat. Genet. 25(3):279-83. doi: $10.1038 / 77033$.

Gorlov I., Kolosov Y., Shirokova N., Getmantseva L., Slozhenkina M., Mosolova N., Bakoev N., Leonova M., Kolosov A., Zlobina E. (2017) Association of the growth hormone gene polymorphism with growth traits in Salsk sheep breed. Small Ruminant Research. 150:11-4. ttps:// doi.org/10.1016/j.smallrumres.2017.02.019.

Guan Feng, Liu Shou-Ren, Shi Guo-Qing, Yang Li-Guo. (2007) Polymorphism of $\mathrm{Fec} B$ gene in nine sheep breeds or strains and its effects on litter size, lamb growth and development. Anim. Reprod. Sci. 99(1-2):44-52. doi: 10.1016/j.anireprosci.2006.04.048.

Fogarty N. (2009). A review of the effects of the Booroola gene (FecB) on sheep production. Small Ruminant Research 85: 75-84. https://doi.org/10.1016/j.smallrumres. 2009.08.003.

Hedrick PW. (2003) Genetika populyatsiy (Genetics of populations). Moscow, Technosphera. $592 \mathrm{p}$.

Ibeagha-Awemu EM, Kgwatalala P, Zhao X. (2008) A critical analysis of production-associated DNA polymorphisms in the genes of cattle, goat, sheep, and pig. Mam. Genome. 19(9):591-617. doi: 10.1007/s00335-008-9141-x.

Jamshidi Reza, Kasirian Mohammad Mahdi, Rahimi Ghodrat Allah. (2013) Application of PCR-PDRF technique to determine Booroola gene polymorphism in the Sangsari sheep breed of Iran. Turk. J. Vet. Anim. Sci. 37: 129-33. doi: 10.3906/vet-0806-14.

Jia JL, Zhang LP, Wu JP, Ha ZJ, Li WW. (2014) Study of the correlation between GH gene polymorphism and growth traits in sheep. Genet. Mol. Res. 13(3):7190-200. doi: 10.4238/2014.September.5.5.

Kumari R, Kumar R, Meena AS, Jyotsana B, Prince LLL, Kumar S. (2014) Genetic polymorphism of growth hormone gene in native sheep breeds of India. Ind. J. Small Rumin. 20(2):15-8.

Lazar Cristina, Glas AlM, Rotar MC, Pistol Gina Cecilia, Pelmus Rodica Stefania, Ghita Elena. (2016) Identi- 
fication of myostatin gene polymorphism using PCRRFLP for Improving Carcass Meat Evaluation of Teleorman Black Head Lambs. Scientific Papers: Anim. Sci. Biotechnol. 49(1):63-8.

Merkureva E. (1977). Geneticheskie osnovy selektsii v skotovodstve [The Genetic Basis of Selection in the Cattle Breeding]. Moscow: Kolos [in Russian].

Miar Y, Salehi A, Kolbehdari D, Ahmad Aleyasin S. (2014) Application of myostatinin sheep breeding programs. Molecular Biology Research Communications. 3 (1):33-43.

Mokhtar Ghaffari, Ardeshir Nejati-Javaremi, Gnodrat Rahimi (2009) Detection of Polymorphism in BMPRIB Gene Associated with Twining in Shal Sheep using PCR-RFLP Method. Intern. J. Agric. Biol. 11(1):97-9.

Montgomery GW, Crawford AM, Penty JM, Dodds KG, Ede AJ, Henry HM, Pierson CA, Lord EA, Galloway Schmack AE, Sise JA, Swarbrick PA, Hanrahan Hill DF. (1993) The ovine Booroola fecundity gene (FecB) is linked to markers from a region of human chromosome 4q. Nat. Genet. 4:410-14. https://doi: 10.1038/ng0893-410.

Nagaki N. (1972) The B blood group polymorphism in the chicken. 2 , The distribution of the alleles in serum breeds. Jap. J. Zootechn. 43 (12): 712-8.

Nei M, Chesser RK. (1983) Estimation of fixation indices and gene diversities. Ann. Hum. Genet., 47(3):253-9. https://doi.org/10.1111/j.1469-1809.1983.tb00993.x.

Ofir R, Gootwine E. (1997) Ovine growth hormone gene duplication - structural and evolutionary implications. Mammalian Genome. 8:770-2. https://doi: 10.1007/s003359900563.

Palmer BR, Roberts N, Kent MP. (1997) A candidate gene approach to animal quality traits. Proc. NZ Soc. Anim. Prod. 57:294-6.

Polley S, De S, Batabyal S, Kaushik R, Yadav P, Arora JS, Chattopadhyay S, Pan S, Biswajit Brahma, Tirtha Kumar Datta, Surender Lal Goswami. (2009) Polymorphism of fecundity genes (BMPR1B, BMP15 and GDF9) in the Indian prolific Black Bengal goat. Small Rum. Res. 85(2-3):1229. https:doi.org/10.1016/j.small-rumres.2009.08.004.

Shabir M, Ganai TAS. (2019) Nucleotide sequencing and DNA polymorphism studies of BMP 15 gene in Corriedale and local Kashmir valley sheep (Ovis aries). Gene. 499(1):231-5. doi: 10.1016/j.gene.2012.02.019.

Shahroudi FE, Nassiry MR, Valizadh R, Moussavi AH, Pour MT, Ghiasi H. (2006) Genetic polymorphism at MTNR1A, CAST and CAPN loci in Iranian Karakul sheep. Iran. J. Biotechnol. 4(2):117-22.

Smith JM, Haigh J. (1974) The hitch-hiking effect of a favourable gene. Genet. Res. 23:23-35. https://doi.org/ $10.1017 / \mathrm{s} 0016672300014634$.

Szkudlarek-Kowalczyk, M, Wiśniewska, E, Mroczkowski S. (2011) Polymorphisms of calpastatin gene in sheep. J. Centr. Eur. Agric. 12(3):425-32. doi: org/10.5513/jcea01/12.3.934.

Wallis M, Lioupis A, Wallis OC. (1998) Duplicate growth hormone genes in sheep and goat. J. Mol. Endocrinol. 21(1):1-5. https://doi.org/10.1677/jme.0.0210001.

Zhou H, Hickford JG, Fang Q. (2008) Variation in the coding region of the myostatin (GDF8) gene in sheep. Mol. Cell. Probes. 22(1):67-8. doi: 10.1016/j.mcp.2007.08.004.

Yilmaz O, Sezenler T, Ata N, Yaman Y, Cemal I, Karaca O (2014) Polymorphism of the ovine calpastatin gene in some Turkish sheep breeds. Turk J Vet Anim Sci. 38: 354-7. doi:10.3906/vet-1401-13. 